\title{
IAMJ
}

INTERNATIONAL

AYURVEDIC

MEDICAL JOURNAL

doi) 2 (요

Research Article

ISSN: 2320-5091

Impact Factor: 6.719

\section{A CLINICAL STUDY TO ASSESS THE EFFICACY OF SHWASAHARA DASHEMANI GHANAVATI IN CARDIAC ASTHMA W.S.R L.V.F}

\author{
$\underline{\text { Roopa M.R }^{1} \text {, Vasudev A Chate }}{ }^{2}$, Shreevathsa ${ }^{3}$, Mohan Kumar $\mathbf{G}^{4}$
}

${ }^{1}$ PG Scholar, Dept. of PG Studies in Ayurveda Samhita and Siddhanta, Govt Ayurveda Medical College, Mysore, Karnataka, India

${ }^{2}$ Associate Professor, Dept. of PG Studies in Ayurveda Samhita and Siddhanta, Govt Ayurveda Medical College, Mysore, Karnataka, India

${ }^{3}$ Prof and HOD, Dept. of PG Studies in Ayurveda Samhita and Siddhanta, Govt Ayurveda Medical College, Mysore, Karnataka, India

${ }^{4}$ Consultant Physician and Intensivist, Vidyaranya Multi Specialty Hospital, Mysore, Karnataka, India

\section{Corresponding Author: roopam.r71@gmail.com}

\section{https://doi.org/10.46607/iamj04p6012021}

(Published online: November 2021)

Open Access

(C) International Ayurvedic Medical Journal, India 2021

Article Received: 18/09/2021 - Peer Reviewed: 07/10/2021 - Accepted for Publication: 08/10/2021

Check for updates

\section{ABSTRACT}

Introduction: Shwasa is said as Shigrapranahara Roga. It occurs as the main disease and also a symptom in various diseases. Shwasakruchrata is a common symptom that occurs in Hrudroga. Acharya Charaka mentioned the unique classification of drugs based on their action. Shwasahara Dashemani is one among them. It is containing 10 herbal drugs which are specially indicated in Shwasa Roga. Hence to evaluate the efficacy of Shwasahara Dashemani in Lakshana Roopi Shwasa in L.V.F (Cardiac Asthma) has taken for the study. Aim and Objective: The objective is to assess the efficacy of Shwasahara Dashemani in L.V.F with dyspnea (Cardiac Asthma). Method: The present study is a controlled comparative, open-label, clinical trial with pre and post-test design. A total of 40 subjects of a diagnosed case of L.V.F with dyspnea (Cardiac Asthma) were selected by using a simple random sampling method. Control group subjects were intervened with standard treatment of L.V.F and intervention group subjects were intervened with standard treatment of L.V.F along with Shwasahara Dashemani Ghana Vati, for the duration of 30 days. Its efficacy was assessed before treatment $\left(0^{\text {th }}\right.$ day) and after treatment $\left(31^{\text {st }}\right.$ day) by using BDI (Baseline 
Dyspnea Index Scale). Results: The P-value of dyspnea of the control group is 1.000 and the P-value of dyspnea of the intervention group is 0.105 . This shows that the results of both groups are statistically not significant. But as compared to the control group, the intervention group is clinically significant because after the intervention $35 \%$ of subjects had shown improvement in the intervention group. Conclusion: As compared to the control group, in the intervention group Shwasahara Dashemani Ghanavati is clinically significant in relieving cardiac asthma when used with standard treatment of L.V.F.

Keyword: Shwasahara Dashemani. Cardiac Asthma, L.V.F, Dyspnea

\section{INTRODUCTION}

Shwasa is the Pranavahasroto Vyadhi ${ }^{[1]}$. It will occur both as the main disease and symptom in many diseases. It is also one of the common symptoms of Hrudroga (heart disease) ${ }^{[2]}$. Heart failure is a complex clinical syndrome that results from structural or functional impairment of ventricular filling or ejection of blood, which in turn leads to the cardinal symptoms dyspnea and fatigue and signs of heart failure namely edema and rales. ${ }^{[3]}$ Cardiac Asthma means dyspnea with expiratory wheeze which occurs in cardiac disease. Acharya Charaka has mentioned a group of 10 drugs especially for Shwasa, which are named as Shwasahara Dashemani based on the Karma i.e, Shwasaharatwa ${ }^{[4]}$ Hence to evaluate the efficacy of Shwasahara Dashemani in Lakshana Roopi Shwasa in L.V.F (Cardiac Asthma) has taken for the study.

\section{The objective of the Study}

The objective is to assess the efficacy of Shwasahara Dashemani in L.V.F with dyspnea (Cardiac Asthma)

\section{Materials and Methods}

The present clinical intervention has been cleared by the Institutional Ethics Committee with reference no IRC-EC/SS (3)/2018-2019 Dated on March 22, 2019, and also, the present clinical intervention was registered in CTRI (Clinical Intervention Registry of India), CTRI registration number is CTRI/2021/04/032624. Source of data and Study design

For the present study, the source of data was selected from the OPD and IPD of GAMC, Mysore and Vidyaranya multi-speciality Hospital, Chamundipuram, Mysore. The research design is a controlled comparative, open-label, clinical trial with pre and posttest design. A total of 44 subjects were registered, there were 4 dropouts. The study was completed in 40 subjects i.e 20 subjects in the control group and 20 subjects in the intervention group and data of 40 subjects were collected.

\section{Inclusion Criteria}

- Diagnosed case of L.V.F with Dyspnea (Ejection Fraction 35-39\%)

- Subjects with diagnosed cases of L.V.F with the age of 40 to 60 years, irrespective of gender were included in the study.

\section{Exclusion Criteria}

- Subjects with the life-threatening type of L.V.F with $\mathrm{EF}$ less than $35 \%$ associated with complications

\section{Intervention}

20 subjects of the control group were intervened with standard treatment (Allopathic) of L.V.F. i.e Angiotensin-converting enzyme inhibitors, Beta Blockers, Angiotensin Receptor Blockers, Aldosterone receptors blockers, Arteriovenous Vasodilators and Diuretics. 20 subjects with the intervention group were intervened with standard treatment (Allopathic) of L.V.F along with Shwasahara Dashemani Ghana Vati, $3 \mathrm{gm} /$ day (6 tablets-500mg each) in 3 divided doses after the food along with warm water for the duration of 30 days. Data was collected before intervention $\left(0^{\text {th }}\right.$ day) and after treatment ( $31^{\text {st }}$ day).

Intervention Drug: The intervention drug Shwasahara Dashemani Ghanavati was procured from GMP certified company i.e. Vishwachaitanya Ayurvediya Rasashala, Baramati, Pune, Maharashtra. Quality analysis of the finished product was done. Details of Shwashahara Dashemani drugs and their scientific name, Family, Preclinical outcome and Rasapanchaka, Doshaghna Karma is shown in Table 1 and 2. 


\begin{tabular}{|c|c|c|c|c|c|}
\hline $\begin{array}{l}\text { SI } \\
\text { No }\end{array}$ & $\begin{array}{l}\text { Sanskrit } \\
\text { Name }\end{array}$ & Scientific Name & Family & $\begin{array}{l}\text { Part } \\
\text { Used }\end{array}$ & Preclinical outcomes \\
\hline 1 & Shati & $\begin{array}{l}\text { Hedychium spi- } \\
\text { catum Ham.Ex } \\
\text { Smith }\end{array}$ & Zingiberace & Rhizome & $\begin{array}{l}\text { Analgesic and Anti-Inflammatory action, antimi- } \\
\text { crobial action. }{ }^{5]}\end{array}$ \\
\hline 2 & $\begin{array}{l}\text { Pushkara } \\
\text { Moola }\end{array}$ & $\begin{array}{l}\text { Inula racemose } \\
\text { Hook.F. }\end{array}$ & Astracea & Root & $\begin{array}{l}\text { Cardioprotective action, Adrenergic Beta } \\
\text { Blocking action, Antiallergic action, Anti-inflam- } \\
\text { matory \& Analgesic action. }{ }^{6]}\end{array}$ \\
\hline 3 & Amlavetas & $\begin{array}{l}\text { Garcinia peduncu- } \\
\text { late Roxb. }\end{array}$ & Guttiferae & $\begin{array}{l}\text { Dried } \\
\text { fruit rind }\end{array}$ & - \\
\hline 4 & Ela & $\begin{array}{l}\text { Elettaria carda- } \\
\text { momum Maton. }\end{array}$ & Zingiberacae & Seeds & Bronchodilator action $^{[7]}$ \\
\hline 5 & Hingu & $\begin{array}{l}\text { Ferula narthex } \\
\text { Boiss }\end{array}$ & Umbelliferae & Gum resin & $\begin{array}{l}\text { Antihypertensive action, Smooth muscle relax- } \\
\text { ant action, Anti-coagulant action \& Antispas- } \\
\text { modic action. }{ }^{[8]}\end{array}$ \\
\hline 6 & Aguru & $\begin{array}{l}\text { Aquilaria agal- } \\
\text { locha Roxb }\end{array}$ & Thymelaeaceae & $\begin{array}{l}\text { Heart- } \\
\text { wood }\end{array}$ & Anti-microbial action ${ }^{[9]}$ \\
\hline 7 & Surasa & $\begin{array}{l}\text { Ocimum santum } \\
\text { Linn }\end{array}$ & Lamiaceae & $\begin{array}{l}\text { Whole } \\
\text { plant }\end{array}$ & $\begin{array}{l}\text { Anti-microbial action, Immunologic action, } \\
\text { Anti-anaphylactic, Antihistaminic and Mast cell } \\
\text { stabilizing action \& cardio protective action }{ }^{[10]}\end{array}$ \\
\hline 8 & Tamalaki & $\begin{array}{l}\text { Phyllanthus Niruri } \\
\text { Linn }\end{array}$ & Euphorbiaceae & $\begin{array}{l}\text { Whole } \\
\text { plant }\end{array}$ & - \\
\hline 9 & Jivanti & $\begin{array}{l}\text { Lepdenia reticu- } \\
\text { lata } \mathrm{W} \& \mathrm{~A} \text {. }\end{array}$ & Asclepiadaceae & $\begin{array}{l}\text { Whole } \\
\text { plant }\end{array}$ & $\begin{array}{l}\text { Antibacterial action, Anti-asthmatic action (Anti- } \\
\text { histaminic action). }{ }^{[11]}\end{array}$ \\
\hline 10 & Chanda & $\begin{array}{l}\text { Angelica glauca } \\
\text { Edgew }\end{array}$ & Apiaceae & Root & $\begin{array}{l}\text { Antimicrobial action, Inhibition of Acetylcholin- } \\
\text { esterase action. }{ }^{[12]}\end{array}$ \\
\hline
\end{tabular}

Table 2: Showing the Rasapanchaka of Shwasahara Dashemani

\begin{tabular}{|l|l|l|}
\hline Rasa & No of Drugs & Shwasahara Dashemani Drugs \\
\hline Katu & 8 & Shati, Pushakaramuala, Hingu, Aguru, Surasa, Tamalaki, Chanda, Ela \\
\hline Tikta & 5 & Shati, Pushkaramula, Aguru, Chanda, Tulasi \\
\hline Kashaya & 2 & Shati, Tamalaki \\
\hline Amla & 2 & Tamalaki, Jivanti \\
\hline Guna & 1 & Amlavetasa \\
\hline Laghu & 9 & $\begin{array}{l}\text { Shati, Pushakaramuala, Hingu, Aguru, Surasa, Tamalaki, Chanda, Ela, } \\
\text { Amlavetasa }\end{array}$ \\
\hline Rooksha & 5 & Amlavetasa Surasa, Tamalaki, Chanda, Ela \\
\hline Tikshna & 5 & Shati, Pushkaramula, Agaru, Chanda, hingu \\
\hline Snigdha & 2 & Jivanti, Agaru \\
\hline Virya & 8 & Shati, Pushakaramuala, Hingu, Aguru, Surasa, Amlavetasa, Chanda, Ela \\
\hline Ushna & 2 & Tamalaki, Jivanti \\
\hline Sheeta & & Shati, Pushakaramuala, Hingu, Aguru, Surasa, Chanda, Ela \\
\hline Vipaka & 7 & Tamalaki, Jivanti \\
\hline Katu & 2 & \\
\hline Madhura & & \\
\hline
\end{tabular}




\begin{tabular}{|l|l|l|}
\hline Amla & 1 & Amlavetasa, \\
\hline Doshaghna Karma & & \\
\hline Vata-Kapha Shamaka & 7 & Shati, Pushakaramuala, Hingu, Aguru, Surasa, Chanda, Amlavetasa, \\
\hline Tridosha-Shamaka & 2 & Ela, Jivanti \\
\hline Pitta-Kapha Shamaka & 1 & Tamalaki \\
\hline Pittavardhaka & 3 & Hingu, Agaru, Tulasi \\
\hline
\end{tabular}

\section{Assessment}

Data were collected before starting the treatment, after the completion of the intervention. The duration of the study was 30 days with pre-assessment on $0^{\text {th }}$ day and post-assessment on the $31^{\text {st }}$ day

\section{Assessment parameters}

The findings were subjected to analysis before and after the intervention by using BDI (Baseline Dyspnea Index Scale) is shown in Table 3

\begin{tabular}{|c|c|c|}
\hline \multicolumn{3}{|c|}{ Baseline Functional Impairment } \\
\hline Grade1 & $\begin{array}{l}\text { Severe } \\
\text { impair- } \\
\text { ment }\end{array}$ & Subject unable to work /has given up most or all usual activities due to shortness of breath \\
\hline Grade 2 & $\begin{array}{l}\text { Moderate } \\
\text { impair- } \\
\text { ment }\end{array}$ & $\begin{array}{l}\text { Subject has changed jobs and /or has abandoned at least one usual activity due to shortness of } \\
\text { breath }\end{array}$ \\
\hline Grade 3 & $\begin{array}{l}\text { Slight } \\
\text { impair- } \\
\text { ment }\end{array}$ & $\begin{array}{l}\text { Distinct impairment in at least one activity but no activities completely abandoned. Reduction, } \\
\text { inactivity at work or in usual activity, that seems slight or not caused by shortness of breath }\end{array}$ \\
\hline Grade 4 & $\begin{array}{l}\text { No } \\
\text { impair- } \\
\text { ment }\end{array}$ & Able to carry out usual activity and occupation without shortness of Breath \\
\hline \multicolumn{3}{|c|}{ Baseline Magnitude of Task } \\
\hline Grade1 & Light & Becomes short of breath with light activities such as walking on the level, washing or standing. \\
\hline Grade 2 & Moderate & $\begin{array}{l}\text { Becomes short of breath with moderate or average tasks such as walking up a gradual hill, climb- } \\
\text { ing fewer than three flights of stairs, or carrying a light load on the level. }\end{array}$ \\
\hline Grade 3 & Major & $\begin{array}{l}\text { Becomes short of breath only with major activities as walking up a steep hill, climbing more than } \\
\text { three flights of stairs, or carrying a moderate load on the level }\end{array}$ \\
\hline Grade 4 & $\begin{array}{l}\text { Extraordi- } \\
\text { nary }\end{array}$ & $\begin{array}{l}\text { Becomes short of breath only with extraordinary activity such as carrying very heavy loads on the } \\
\text { level, lighter load uphills, or running. No Shortness of breath with ordinary tasks }\end{array}$ \\
\hline \multicolumn{3}{|c|}{ Baseline Magnitude of Effort } \\
\hline Grade1 & Light & $\begin{array}{l}\text { Becomes short of breath with little effort. Task performed with little effort or more difficult tasks } \\
\text { performed with frequent pauses and requiring 50-100\% longer to complete than the average per- } \\
\text { son might require. }\end{array}$ \\
\hline Grade 2 & Moderate & $\begin{array}{l}\text { Becomes short of breath with moderate effort. Tasks are performed with occasional pauses and } \\
\text { require longer to complete than the average person. }\end{array}$ \\
\hline Grade 3 & Major & $\begin{array}{l}\text { Becomes short of breath effort distinctly submaximal, but of major portion. Tasks are performed } \\
\text { without pause unless the task requires an extraordinary effort that may be performed with pauses. }\end{array}$ \\
\hline Grade 4 & $\begin{array}{l}\text { Extraordi- } \\
\text { nary }\end{array}$ & $\begin{array}{l}\text { Becomes short of breath only with the greatest imaginable effort. No shortness of Breath with } \\
\text { ordinary effort }\end{array}$ \\
\hline
\end{tabular}




\section{Statistical Methods}

The results of the present study were analyzed statistically by applying inferential statistical methods. The software used is SPSS Version 16.0
Results: Distribution of subjects based on the severity of overall symptoms of BDI scale before and after the treatment as shown in Tables No-4 and 5.

Table 4: Results of Baseline Functional Impairment before and after the treatment

\begin{tabular}{|c|c|c|c|c|}
\hline \multirow{2}{*}{\multicolumn{2}{|c|}{ Groups }} & \multicolumn{2}{|c|}{ BFI } & \multirow{3}{*}{$\begin{array}{l}\text { Total } \\
20(100.0 \%)\end{array}$} \\
\hline & & \multirow{2}{*}{$\begin{array}{l}\text { Moderate } \\
16(80.0 \%)\end{array}$} & \multirow{2}{*}{$\begin{array}{l}\text { Slight } \\
4(20.0 \%)\end{array}$} & \\
\hline Control & BT & & & \\
\hline & AT & $16(80.0 \%)$ & $4(20.0 \%)$ & $20(100.0 \%)$ \\
\hline \multirow{2}{*}{ Intervention } & BT & $15(75.0 \%)$ & $5(25.0 \%)$ & $20(100.0 \%)$ \\
\hline & AT & $9(45.0 \%)$ & $11(55.0 \%)$ & $20(100.0 \%)$ \\
\hline
\end{tabular}

Table 5: Results of Baseline Magnitude of Task and Baseline Magnitude of Effort before and after the treatment

\begin{tabular}{|l|l|l|l|l|}
\hline \multirow{2}{*}{ Groups } & \multicolumn{2}{|c|}{ BMT and BME } & \multicolumn{2}{l|}{ Total } \\
\cline { 3 - 5 } & Moderate & Major & \\
\hline \multirow{2}{*}{ Control } & BT & $16(80.0 \%)$ & $4(20.0 \%)$ & $20(100.0 \%)$ \\
\cline { 2 - 4 } & AT & $16(80.0 \%)$ & $4(20.0 \%)$ & $20(100.0 \%)$ \\
\hline \multirow{2}{*}{ Intervention } & BT & $15(75.0 \%)$ & $5(25.0 \%)$ & $20(100.0 \%)$ \\
\cline { 2 - 4 } & AT & $9(45.0 \%)$ & $11(55.0 \%)$ & $20(100.0 \%)$ \\
\hline
\end{tabular}

In the control group, there was no change in BFI, BMT and BME before and after the intervention. In the intervention group after the intervention, $35 \%$ of the subjects had reported improvement in BFI, BMT and BME.

\section{Statistics - Pearson chi-square test}

P-Value and significance of both control group and intervention group in relieving dyspnea is given in Table 6

Table 6: Statistical significance of Dyspnea, Control and Intervention Group

\begin{tabular}{|c|c|c|c|c|c|}
\hline \multirow[t]{2}{*}{ Parameters } & \multicolumn{2}{|c|}{ Control group } & \multicolumn{2}{|c|}{ Intervention group } & Statistical Test \\
\hline & P-value & Remarks & P-value & Remarks & Pearson chi-square \\
\hline BFI & \multirow{3}{*}{1.000} & \multirow{3}{*}{$\begin{array}{l}\text { Statistically not } \\
\text { Significant }\end{array}$} & \multirow{3}{*}{0.105} & \multirow{3}{*}{$\begin{array}{l}\text { Statistically not } \\
\text { Significant }\end{array}$} & \multirow[t]{3}{*}{ Fisher's exact test } \\
\hline BMT & & & & & \\
\hline BME & & & & & \\
\hline
\end{tabular}

\section{DISCUSSION}

Dyspnea is a subjective experience of breathing discomfort, that consists of qualitatively distinct sensations that are very in intensity. ${ }^{[14]}$ In L.V.F the left ventricle of the heart has no longer pumps enough blood. As a result, blood builds up in the pulmonary veins, which causes dyspnea. Orthopnea and Paroxysmal Nocturnal Dyspnea (PND) are the clinical symptoms of Heart Failure (HF) with reduced ejection fraction, and it is treated with Angiotensin-converting enzyme inhibitors, Beta Blockers, Angiotensin Receptor
Blockers, Aldosterone receptors blockers, Arteriovenous Vasodilators and Diuretics. The preclinical outcome of Shwasahara Dashemani is known for their activities such as cardioprotective action and Inhibition of Acetylcholinesterase action. Cardioprotective action includes improvement in the precordial pain and dyspnea, a significant reduction in cholesterol, triglycerides and total lipid level. Improve antioxidant status, hemodynamic and left ventricular contractile function subsequent to suppression of oxidative stress. 
It was observed that, during the trial period as compared to the control group, $65 \%$ of subjects of the intervention group, have reported increased frequency of urination as compared to the baseline period. Karma of Mutra is Kledavahana (removal of excessive $K l e d a)$ it can be correlated with diuretic action.

Hrudaya is the Moola of Pranavaha and Rasavaha Srotas, any abnormality in the Hrudaya leads to vitiation of Pranavaha and Rasavaha Srotas, in turn, leads to Shwasa in Hrudroga. Sthana of Vyanavayu is Hrudaya, vitiation of this leads to Hrudroga. Among Shwasahara Dashemani most of the drugs have Ushna Virya, Kaphavatahara, Deepana, Pachana and Anulomana properties. Ushna Virya and Anulomana action of Shwasahara Dashemani helps in Hrudroga.

Shwasa is the Pittashtana Samudbhava, Kaphavata Pradhana Vyadhi and derangement of Agni is there, Shwasahara Dashemani acts on all these components which are involved in the manifestation of Shwasa.

Both Shwasa and Hrudroga are Amashaya Samudbhava Vyadhi, Deepana and Pachana action of Shwasahara Dashemani helps in Lakshana Roopi Shwasa of Hrudroga

Haratwa property of Shawsa is to be understood by this. Karma which relieves the Shwasa is called Shawsahara Dasheamani.

Here in this study sample size is small and two nominal variables are there, hence Pearson chi-square Fisher's exact test is used for statistical analysis.

The P-value of dyspnea of the control group is 1.000 and the P-value of dyspnea of the intervention group is 0.105 . This shows that the results of both groups are statistically not significant. But as compared to the control group, the intervention group is clinically significant because after the intervention $35 \%$ of subjects had shown improvement in the intervention group.

\section{CONCLUSION}

As compared to the control group, in the intervention group Shwasahara Dashemani Ghanavati is clinically significant in relieving cardiac asthma when used with standard treatment of L.V.F. Thus, Shwasaharatwa
Karma of Shwasahara Dashemani is clinically significant and evident in Lakshana Roopi Shwasa in Hrudroga (L.V.F with dyspnea).

\section{REFERENCES}

1. Charaka Samhita, Vimana Sthanam, Sroto Vimana Adhyaya, 5/8 Available from http;//niimh.nic.in/ebook/echaraka [ Last accessed on 14 September 2021]

2. Charaka Samhita, Chikitsa Sthanam, Trimarmiya Chikitsa Adhyaya,26/78. Available from: http;//niimh.nic.in/ebook/echaraka [ Last accessed on 14 September 2021]

3. Jemeson, Faugi, Kasper, Longo, Harrison's Principles of Internal medicine, $20^{\text {th }}$ Edition Vol-2: Mc Graw Hill Education Publication.New Delhi. P No-1763

4. Charaka Samhita, Sutra Sthanam, Shadvirechanashatshritiya Adhyaya, 4/16. Available from: http;//niimh.nic.in/ebook/echaraka [ Last accessed on 14 September 2021]

5. Sravani T, Padmaa M Paarakh. Pharmacologyonline; Hedychium spicatum Buch.Ham. -An overview: Pharmacologyoline 2: 2011 [P No-638-639]

6. Dr G. P kimothi; Pushkaramoola (Innula racemose Hook.f.) A drug with potential Bronchodilatory properties. Info Ayurveda: April-June2014 Vol-10 [P No;2122]

7. Arif-ullah khan, Qaiser Jabeen Khan and Anwarul-Hassan Gilani: Pharmacological basis for the medicinal use of cardamom in Asthma; A Journal of the Bangladesh Pharmacological Society -2011. Vol-6. [P No- 37]

8. Arshiya Sultan, Asma K, Khaleequr Rahman and Shafeequr Rahman; Oleo-gum-resin of Ferula Asafoetida: A traditional culinary spice with versatile pharmacological activities; International Science Congress Association. 2015 Vol-4. [P No-21]

9. Manasi Dash, Jayanta Kumar Patra, Prasanna Priyadarshini Panda. Full-length research paper on Phytochemical and antimicrobial screening of extracts of Aquilaria Agallocha Roxb. African Journal of Biotechnology. October-2008, Vol-7 [P No-3532]

10. Siva M, Shanmugam KR, Shanmugam B, Venkata Subbaiah G, Ravi S, Sathyavelu Reddy k. Mallikarjun K. Ocimum Sanctum: a review on the pharmacological properties; International Journal of Basic and Clinical Pharmacology, May-June-2016, Vol-5 [P No-560-563]

11. Jayesh M. Dhalani, Pankaj B. Nariya; A Pharmacological Review: Leptadenia reticulata (Wight \& Arn.) 
Jivanti: the real-Life giving Plant. Folia Medica-2017. Vol-59. [P No-405-411]

12. Anupam Maurya, Subash v Verma, Vijay Gupta, M.B. Shankar; Angelica archangelica L- A phytochemical and pharmacological Review, Asian Journal of Research in Chemistry - Nov-Dec-2017 [P No-854-855]

13. Dr. Donald A Mahler, David H. weinberg, Carolyn K. Wells and Alavan R. Feinstien. www.thoracic.org

14. Jemeson, Faugi, Kasper, Longo, Harrison's Principles of Internal medicine, 20 ${ }^{\text {th }}$ Edition Vol-1: Mc Graw Hill Education Publication.New Delhi. P No-226

\section{Source of Support: Nil \\ Conflict of Interest: None Declared}

How to cite this URL: Roopa M. R et al: A Clinical Study To Assess The Efficacy Of Shwasahara Dashemani Ghanavti In Cardiac Asthma W.S.R L.V.F. International Ayurvedic Medical Journal \{online\} 2021 \{cited November 2021\} Available from: http://www.iamj.in/posts/images/upload/3179_3185.pdf 